\title{
Jan Bobrzyński, Zwierciadło gasnqquego świata. Pamiętnik z ćwierćwiecza na służbie ojczyzny, wstęp i opracowanie T. Sikorski, A. Wątor, Kraków 2019, ss. 400
}

W 2019 r. w ramach serii Biblioteka Klasyki Polskiej Myśli Politycznej ${ }^{1}$ została wydana książka: Jan Bobrzyński Zwierciadło gasnacego świata. Pamiętnik z ćwierćwiecza na stużbie ojczyzny. Naukowo pamiętnik opracowali doświadczeni badacze Tomasz Sikorski oraz Adam Wątor, którzy od wielu lat podejmują trud upowszechniania materiałów źródłowych do badania polskiej myśli politycznej XX w. Książka została wydana przez Krakowski Ośrodek Myśli Politycznej. Instytucja ta działa na rzecz upowszechniania osiągnięć polskiej myśli politycznej XIX i XX w., publikując nie tylko wybory pism postaci utożsamianych z różnymi nurtami politycznymi, ale również organizując konferencje i dyskusje.

Książka jest efektem ożywienia badań nad polskim konserwatyzmem, które można zaobserwować w ostatnich latach. Warto dodać, że Jan Bobrzyński jest nieco

\footnotetext{
1 „Biblioteka Klasyki Polskiej Myśli Politycznej” jest projektem badawczym i edytorskim poświęconym dziedzictwu polskiej myśli politycznej minionych stuleci. W ciągu 19 lat w serii tej powstało już ponad 100 tomów zawierających książki, broszury i artykuły myślicieli, przedstawicieli różnych nurtów polskiej myśli i zaangażowanych w jej najważniejsze dyskusje. Zob. J. Kloczkowski, Warto zaczać od tradycji. Rzecz o serii „Biblioteka Klasyki Polskiej Myśli Politycznej”, Myśl Polityczna. Political Thought 1 (2019), s. 209-225.

2 Zob. S. Głąbiński. Wspomnienie polityczne, wstęp i opracowanie T. Sikorski, A. Wątor, Kraków 2017; Stanisław Kozicki. Pół wieku polityki demokratyczno-narodowej (1887-1939), tamże; Korespondencja i papiery polityczne Jana Gwalberta Pawlikowskiego z lat 1904-1914, wstęp i opracowanie T. Sikorski, A. Wątor, Szczecin 2014; Julian Nowak. Wspomnienia z ławy rządowej, wstęp i opracowanie T. Sikorski, H. Walczak, A. Wątor, Kraków 2017; Dziennik Juliusza Zdanowskiego, przedmowa i opracowanie J. Faryś, T. Sikorski, H. Walczak, A. Wątor, Szczecin 2015.
} 
zapomnianą i niedocenioną przez historiografię postacią. Chcąc dorównać ojcu ${ }^{3}$, $\mathrm{w}$ dwudziestoleciu międzywojennym zaangażował się w politykę, ale nie radził sobie w tej roli zbyt dobrze. Na pewno był doskonałym chemikiem, wyróżniającym się publicystą i nietypowym konserwatystą. Osobowość ciekawa, której warto poświęcić uwagę z jeszcze jednego powodu: jest doskonałym przykładem dostosowania się konserwatysty do życia w niekonserwatywnym świecie.

Dotychczas najszersze badania nad tą postacią przeprowadził Włodzimierz Mich, który w 2009 r. opublikował wartościową książkę zawierającą analizę poglądów Jana Bobrzyńskiego w czasie redagowania przez niego pisma „Nasza Przyszłość”. Jacek Bartyzel poświęcił myśli politycznej Bobrzyńskiego jeden z rozdziałów książki zatytułowanej Konserwatyzm bez kompromisu ${ }^{5}$, natomiast Sebastian Paczos opublikował biografię polityczną J. Bobrzyńskiego ${ }^{6}$. Wzmianki o J. Bobrzyńskim można również znaleźć w pracach poświęconych działalności politycznej konserwatystów, m.in. u Władysława Władyki, Szymona Rudnickiego, Michała Jaskólskiego, Tomasza Sikorskiego czy Bogdana Szlachty.

Na polu upowszechniania materiałów źródłowych pomocnych w zrekonstruowaniu myśli politycznej J. Bobrzyńskiego zrobił wiele Edward Czapiewski, który w 1998 r. wydał opatrzony wstępem wybór publicystyki, a nieco wcześniej fragment pamiętnika znajdującego się w Bibliotece Zakładu Narodowego im. Ossolińskich we Wrocławiu $(\mathrm{ZNiO})^{7}$. W 2014 r. ukazał się natomiast wybór pism polskich konserwatystów z lat 1918-1939 pod redakcją Marcina Króla, w którym zostały zamieszczone trzy teksty J. Bobrzyńskiego dotyczące konserwatyzmu

Materiały odnoszące się do działalności politycznej J. Bobrzyńskiego są dosyć obszerne i rozsiane po różnych archiwach i bibliotekach. Oprócz publicystyki istot-

3 Ojcem Jana był Michał Bobrzyński, wybitny historyk, jeden z twórców krakowskiej szkoły historycznej oraz namiestnik Galicji, zob. W. Łazuga, Michał Bobrzyński. Myśl historyczna a działalność polityczna, Warszawa 1982.

4 Zob. W. Mich, Publicystyka polityczna „Naszej Przyszłości” 1930-1939, Lublin 2009.

5 Zob. J. Bartyzel, Konserwatyzm bez kompromisu. Studium z zachowawczej myśli politycz$n e j w$ Polsce, Toruń 2002. Autor poświęcił Janowi Bobrzyńskiemu trzeci rozdział pracy, zatytułowany „Ostatni Stańczyk - Jan Bobrzyński”.

6 Zob. S. Paczos, Jan Bobrzyński. Portret polityczny, Poznań 2018.

7 E. Czapiewski, Jan Bobrzyński o kwestiach ustrojowych Drugiej Rzeczypospolitej, Warszawa 1998; tenże, Ugrupowania konserwatywne w Polsce $z$ lat 1926-34 we wspomnieniach Jana Bobrzyńskiego, Ze Skarbca Kultury, Wrocław (1975), z. 26, s. 93-167.

8 Konserwatyści polscy 1918-1939. Wybór pism, oprac. M. Król, Warszawa 2014. 
ną rolę w rekonstruowaniu myśli politycznej Bobrzyńskiego odgrywa jego zachowana korespondencja z czołowymi politykami konserwatywnymi z okresu pełnienia funkcji sekretarza Stronnictwa Prawicy Narodowej. Znajduje się ona w Archiwum Państwowym w Krakowie (Archiwum Dzikowskie Tarnowskich) ${ }^{9}$. Osobną grupę materiałów źródłowych stanowią wspomnienia Jana Bobrzyńskiego zatytułowane „Zwierciadło gasnącego świata”, przechowywane w ZNiO. Ta ostatnia rzecz należy do nielicznych zachowanych tego typu źródeł, bowiem w czasie powstania warszawskiego w gruzach kamienicy, w której mieszkał, spłonęły wszystkie jego prywatne listy, zapiski i rękopisy prac oraz oryginał wspomnianego pamiętnika. Bobrzyński odtworzył go po wojnie w Puławach. Maszynopis znajdujący się w Z ZNiO jest niezwykle cennym źródłem pozwalającym odtworzyć prywatną historię samego Bobrzyńskiego, ale jak słusznie zauważają Autorzy tomu, ukazuje panoramę polityki polskiej w ogóle, a przede wszystkim dość precyzyjnie oddaje obraz polskiego konserwatyzmu międzywojennego ${ }^{10}$.

Recenzowana książka składa się z dwóch tylko pozornie odrębnych części. Jest to obszerny wstęp zatytułowany: „Syzyf. Jan Bobrzyński (1882-1951)”, wzbogacony przedmiotową bibliografią (z podziałem na źródła i opracowania). Drugą część stanowi liczący 385 stron opatrzonych przypisami tekst pamiętnika, w którym znajdują się informacje na temat instytucji oraz biogramy postaci pojawiających się w tekście pamiętnika. Redakcja wymagała od Autorów wiele pracy, biorąc pod uwagę, że Bobrzyński odtworzył pamiętnik z pamięci w latach powojennych, co spowodowało liczne usterki, choćby w datowaniu wydarzeń. Poprawili również pojawiające się błędy językowe, dopasowując stylistykę i ortografię do wymogów współczesnej polszczyzny. Cieszy bardzo, że wszelkie komentarze oraz dopiski i skreślenia sporządzone odręcznie przez Bobrzyńskiego zostały przez Autorów uwzględnione i zamieszczone w tekście. W pracy znajdziemy także aneks, w którym znalazł się biogram Bobrzyńskiego, dołączony do pamiętnika przez żonę Marię, oraz korespondencję Bobrzyńskiego z wydawnictwem Teslar, które miało wydać pamiętnik drukiem.

Wstęp przygotowany przez Autorów stanowi doskonałe wprowadzenie do tekstu pamiętnika. W miarę zwięzły sposób udało im się zaprezentować ponad pół wieku życia J. Bobrzyńskiego przy jednoczesnym umiejętnym wskazaniu najważniejszych pól jego zainteresowań. Pewien niedosyt pozostawia poświęcenie przez Autorów

9 Archiwum Narodowe w Krakowie, Oddział na Wawelu, Archiwum Dzikowskie Tarnowskich, sygn. 668, 671, 677, 693, 720, 729-736.

10 J. Bobrzyński, Zwierciadło gasnącego świata. Pamiętnik z ćwierćwiecza na służbie ojczy$z n y$, wstęp i opracowanie T. Sikorski, A. Wątor, Kraków 2019, s. LVIII. 
zbyt mało uwagi kwestiom gospodarczym, które szczególnie zajmowały Bobrzyńskiego. Warto w tym miejscu podkreślić, że w odróżnieniu od wielu konserwatystów kładł on większy nacisk na prawa wolnościowe jednostki (zwłaszcza w sferze gospodarczej), a jego poglądy społeczno-ekonomiczne odbiegały już dość znacznie w stronę liberalizmu. Klamrą spinającą jego poglądy ekonomiczne był obiektywizm gospodarczy, opierający się podobnie jak liberalizm na wolności gospodarowania i nienaruszalności własności prywatnej ${ }^{11}$.

W pierwszych latach niepodległej Polski Bobrzyński pracę urzędniczą łączył z publicystyką, wydając kilka broszur utrzymanych w liberalnym tonie ${ }^{12}$. Zagadnieniem, którym zajmował się szczególnie intensywnie była gazyfikacja węgla ${ }^{13}$, o czym świadczy ilość miejsca, jaką temu zagadnieniu poświęcił w swoim pamiętniku. Teorię postanowił sprawdzić w praktyce i w celu realizacji tego przedsięwzięcia w 1920 r. powołał do życia Towarzystwo Przemysłu Węglowego (TPW), zostając jego przewodniczącym ${ }^{14}$. Pomimo obiecujących początków TPW upadło. Niepowodzenia w biznesie nie złamały go na długo i zaczął szukać innego zajęcia. Nawiązał kontakty z licznymi redakcjami, rozpoczynając długoletnią działalność publicystyczną, którą prowadził aż do wybuchu wojny. Jeszcze przed 1926 r. Jan Bobrzyński współpracował z konserwatystami, ale to zamach majowy miał znaczący wpływ na jego decyzję o zaangażowaniu się w politykę. Doceniając zasługi organizacyjne, powierzono mu funkcję sekretarza generalnego Stronnictwa Prawicy Narodowej. Jan Bobrzyński zachęcony sukcesem rozpoczął wiele działań, które nie znajdowały jednak uznania w oczach członków partii. Chodzi głównie o ideę Zjednoczonego Frontu Gospodarczego, tworzenie nowych oddziałów stronnictwa, sabotowanie działań zmierza-

11 Zob. S. Paczos, Przyczynek do charakterystyki koncepcji gospodarczych Jana Bobrzyńskiego, Polish Biographical Studies (2015), nr 3, s. 33-55.

12 Zob. J. Bobrzyński, Monopole w Polsce, Warszawa 1919; tenże, Polski Bank Emisyjny, Warszawa 1921.

13 Wiązało się to z jego wykształceniem. Skończył studia chemiczne w Karlsruhe, gdzie był uczniem prof. Karla Oswalda Englera. Natomiast w 1910 r. uzyskał z wyróżnieniem stopień doktora na Uniwersytecie Technicznym w Grazu na podstawie pracy opisującej właściwości ropy naftowej.

14 W jego zamierzeniach przedsiębiorstwo to miało w przyszłości przekształcić się w duży koncern przemysłowy na wzór zachodni, działający dzięki współpracy przedsiębiorstw z różnych branż (górniczych, chemicznych i elektryfikacyjnych). Chciał wcielić w życie na gruncie polskim projekt austro-węgierskiego ministra robót publicznych Emila Homana, który w czasie wojny planował stworzenie wielkiej centrali przetwórstwa węglowego na Śląsku Cieszyńskim i przesyłanie z niej gazu aż do Wiednia. 
jących do konsolidacji ugrupowań konserwatywnych oraz miejsca konserwatystów w obozie sanacyjnym.

Postępujące zbliżanie się konserwatystów do obozu piłsudczykowskiego, a następnie utworzenie Zjednoczenia Zachowawczych Organizacji skłoniły Bobrzyńskiego do podjęcia próby usamodzielnienia ${ }^{15}$. W kwietniu $1930 \mathrm{r}$. ukazał się pierwszy numer miesięcznika „Nasza Przyszłość” noszącego podtytuł „Wolna Trybuna Zachowawczej Myśli Państwowej”, a nie - jak piszą Autorzy recenzowanego tomu - „Nasza Przyszłość. Wolna Trybuna Polskiej Myśli Państwowej”. Podtytuł pisma rzeczywiście przybierze taki kształt w 1934 r., gdy rozejdą się ostatecznie drogi Bobrzyńskiego i obozu zachowawczego ${ }^{16}$. Zmiana w podtytule wiązała się również ze zmianą formy działania Koła Przyjaciół „Naszej Przyszłości”, które w grudniu 1934 r. zostało przekształcone w Związek Polskiej Myśli Państwowej. W ramach tej struktury Bobrzyński podjął kilka inicjatyw, a jedną z najistotniejszych był projekt bloku państw środkowo-wschodniej Europy, tj. ścisłego sojuszu militarnego i gospodarczego Polski, Węgier, Litwy, Łotwy, Estonii, Rumunii, Jugosławii i Czechosłowacji, a więc państw położonych w trójkącie niebezpieczeństwa między Bałtykiem, Adriatykiem a Morzem Czarnym. Celem było stworzenie organizmu na tyle silnego, aby przeciwstawić się naciskowi Niemiec i Związku Radzieckiego. Rozwinął także ożywioną działalność sekcji zajmującej się sprawami polsko-litewskimi i polsko-ukraińskimi.

We wstępie szczególnie dużo miejsca Autorzy poświęcili analizie poglądów ustrojowych J. Bobrzyńskiego, podnosząc jego antydemokratyzm, sygnalizując mocne przywiązanie do idei monarchistycznych i określając go jako zwolennika „łagodnego autorytaryzmu" pozostającego wówczas (przed przewrotem majowym) pod wyraźnym urokiem włoskiego faszyzmu (strona XIII). Nie do końca mogę zgodzić się z takim opisem. Jan Bobrzyński inspiracje ustrojowe czerpał ze stańczykowskiej myśli, wytycznych krakowskiej szkoły historycznej i religii katolickiej, dużo mniejsze

1527 II 1933 r. powstało Zjednoczenie Zachowawczych Organizacji Politycznych. Bobrzyński co prawda został wybrany do władz tego nowego ugrupowania, ale nie podjął w nim faktycznej działalności. W lutowym numerze „Naszej Przyszłości” została zamieszczona informacja, że J. Bobrzyński złożył zarówno wszystkie piastowane funkcje w SPN, jak i mandat zastępcy członka Komitetu Zachowawczego (Komunikat Redakcji, Nasza Przyszłość 28 (1933), s. 105).

16 W marcu 1934 r. zmieniono podtytuł pisma na „Trybuna Polskiej Myśli Państwowej” i ograniczono propagowanie idei zachowawczych (Redakcja, Zmiana w podtytule, Nasza Przyszłość 36 (1934), s. 1-2). 
zaś znaczenie miały idee faszyzmu ${ }^{17}$ i rojalizmu ${ }^{18}$. Jego koncepcje ustrojowe zmierzały do znalezienia najlepszego $\mathrm{z}$ możliwych $\mathrm{w}$ danych warunkach modelu państwa i jego ustrojowej organizacji. Nie absolutyzował żadnych zasad społeczno-ustrojowych, starając się wiązać je z potrzebami społeczeństwa znajdującego się na określonym etapie rozwoju. $Z$ biegiem lat jego projekty ustrojowe ulegały zmianom w szczegółach, ale założenia konserwatywnego stylu myślenia pozostawały niezmienne. Istotnym elementem jego poglądów ustrojowych był antydemokratyzm, którego źródeł można doszukiwać się m.in. w krytycznej ocenie funkcjonowania demokracji w Polsce w latach 1919-1926. Propozycje ustrojowe Bobrzyńskiego wykazywały pokrewieństwo z poglądami Władysława Leopolda Jaworskiego, Konstantego Grzybowskiego czy Stanisława Estreichera. W poglądach na ustrój Bobrzyński pozostał do końca wierny realizmowi stańczyków, co szczególnie widać w przekonaniu, że idealny model ustroju nie istnieje, a forma rządu ma w istocie charakter relatywny w stosunku do obiektywnych okoliczności. Dążył do stworzenia ustroju, dopasowanego do aktualnie panujących w Polsce warunków, który z pominięciem wszelkich historycznych doktryn i eksperymentów łączyłby w sobie elementy silnej władzy z możliwie maksymalnym zapewnieniem swobód obywatelskich. Bobrzyński obawiał się statycznych struktur hamujących rozwój społeczny, stąd jego niejednoznaczna postawa wobec idei monarchicznej.

W czasach PRL Bobrzyński nie potrafil do końca odnaleźć się w nowej rzeczywistości. Antykomunistyczne przekonania, z którymi nigdy się nie krył, były powodem szykan ze strony władz, o czym dowiadujemy się z pamiętników jego żony. Trudna sytuacja, w jakiej się znaleźli w Puławach, skłoniła ich do wstąpienia w struktury Polskiej Partii Socjalistycznej, o czym Autorzy wstępu nie wspominają. Formalnie nastąpiło to w czerwcu 1947 r. Swoją decyzję Bobrzyńscy tłumaczyli trudną sytuacją materialną, naciskami władz Państwowego Instytutu Nauk Gospodarstwa Wiejskiego w Puławach oraz perspektywą utraty pracy. O ile Jan pozostawał szere-

17 Nie należy przeceniać zainteresowania Jana Bobrzyńskiego faszyzmem. Zdawał on sobie sprawę z odmienności warunków Polski i Włoch. Jego fascynacja tym ustrojem miała charakter powierzchowny, ponadto wyrażał niezrozumienie dla jego totalistycznej istoty.

18 Konserwatywna koncepcja władzy jest w wielu punktach zbieżna $\mathrm{z}$ koncepcją monarchiczną, ale nie jest jednak konieczną jej konsekwencją. W przekonaniu Bobrzyńskiego atrakcyjność monarchizmu wynikała z tego, że zabezpieczał on zarówno od despotyzmu władców, jak i mas, łącząc siłę władzy z poczuciem jej stałości. Postulat regencji jako formy przejściowej na drodze restauracji monarchii, który pojawił się w „Uproszczonym ustroju państwa polskiego”, był konsekwencją przekonania, że tylko monarcha jest w stanie rozwiązać problem „funkcjonowania” państwa wielonarodowego. 
gowym członkiem koła przy Instytucie o numerze legitymacji 603874, o tyle jego żona była delegatem do Powiatowej Rady PPS, pełniąc funkcję jej sekretarza. Maria zasiadała również w Powiatowej Radzie Politycznej $\mathrm{PPS}^{19}$. Z tego okresu pochodzi jeden z tekstów J. Bobrzyńskiego zatytułowany „Współczesne zadania socjalizmu”20. W tym specyficznym referacie, w którym poza pojedynczymi momentami trudno dopatrzyć się schlebiania ówczesnej władzy, są widoczne dość dobrze przedwojenne poglądy Bobrzyńskiego, zwłaszcza propaństwowe i promodernizacyjne. Słowa, które padają w tym tekście, konserwatysty, zwolennika własności prywatnej, który jeszcze kilka lat wcześniej widział w ideach socjalistycznych największe zagrożenie dla Polski, mogą co najmniej dziwić. Jego wolta światopoglądowa nie była przejawem zagubienia ideowego. Można przypuszczać, że zmuszony życiowymi okolicznościami podjął trudną dla siebie decyzję, dopasowując własne przekonania do potrzeby chwili, przy czym należy poczynić w tym przypadku pewne zastrzeżenia. Jego stosunek do socjalizmu przypomina trochę jego stanowisko wobec demokracji $^{21}$. Bobrzyński częściowo akceptował demokrację formalno-prawną, uznając ją za konieczność dziejową. Utożsamiał ją z nowożytnym ustrojem konstytucyjnym, niemniej właściwy jej sens upatrywał w zasadzie egalitaryzmu i jako taki odrzucał.

Pewne wątpliwości może budzić to, że Autorzy we wstępie posługują się trafnymi cytatami, nie opatrują ich jednak przypisami. Natomiast bardzo pomocny okazuje się indeks nazwisk znajdujący się na końcu książki, zwłaszcza biorąc pod uwagę to, jak dużo pojawia się ich w tekście pamiętnika.

Książka T. Sikorskiego i A. Wątora wpisuje się w szereg prac odsłaniających treść i znaczenie nieco zapomnianych, ale niekiedy bardzo oryginalnych polskich polityków okresu międzywojnia. W zakończeniu recenzji wypada raz jeszcze podkreślić, że Autorzy włożyli w pracę nad pamiętnikiem Jana Bobrzyńskiego mnóstwo wysiłku i trud ten nie poszedł na marne.

Nadesłany: 10 I 2021

Zaakceptowany: 15 I 2021

19 Archiwum Państwowe w Lublinie (APL), Komitet Powiatowy Polskiej Partii Socjalistycznej w Puławach, zespół 35/1260, sygn. 29/2, 29/4, 29/16, 29/17.

20 J. Bobrzyński, Współczesne zadania socjalizmu, referat wygłoszony podczas walnego posiedzenia koła PPS przy Instytucie 20 maja 1948 roku, sekretariat powiatowy - protokoły zebrań kół PPS powiatu Puławy z załącznikami, AKP, zespół 35/1260, sygn. 29/11, s. 108-112.

21 Zob. S. Paczos, Jan Bobrzyński. Portret, s. 257-279. 
Dr hab. Sebastian Paczos, prof. UAM

Wydział Historii

Uniwersytet im. Adama Mickiewicza w Poznaniu

ul. Uniwersytetu Poznańskiego 7

61-614 Poznań 